ROCZNIK PRZEMYSKI t. 57

LITERATURA I JEZYK z. 2 (25) 2021

MONIKA KARDASZ (Kraków)

ORCID: 0000-0002-1644-0719

\title{
RECENZJA: MACIEJ WŁODARSKI, „STAROPOLSKIM SZLAKIEM”, WYDAWNICTWO UNIWERSYTETU JAGIELLOŃSKIEGO, KRAKÓW 2020, SS. 276
}

Przedmiotem mojego zainteresowania jest najnowsza publikacja Macieja Włodarskiego, badacza literatury dawnej, emerytowanego profesora związanego z Katedrą Literatury Staropolskiej Uniwersytetu Jagiellońskiego. Krąg jego zainteresowań badawczych jest bardzo szeroki: od tematyki tanatologicznej w literaturze i kulturze staropolskiej ${ }^{1}$, polsko-łacińskiej poezji średniowiecznej ${ }^{2}$ przez badanie kulturalnych i literackich związków polsko-bazylejskich ${ }^{3}$ aż po twórczość Mikołaja Reja, Jana Kochanowskiego czy Daniela Naborowskiego - zatem obejmuje literaturę trzech epok okresu staropolskiego.

Staropolskim szlakiem to zbiór studiów, spośród których większość została wcześniej opublikowana w czasopismach naukowych i pracach zbiorowych. Mimo to jako pewna nowa całość publikacja ta jawi się interesująco. Wytrawny badacz dokonał starannej selekcji, dlatego czytelnik mojej recenzji nie znajdzie tu zbyt wielu uwag krytycznych. Książkę Włodarskiego - jako młoda badaczka literatury dawnej - traktuję raczej jak pewien wzór analizy i interpretacji, szkołę warsztatu literaturoznawczego i poetyki, naukę podejścia do poezji dawnej z godnym naśladowania pietyzmem.

Książka została podzielona na trzy części dotyczące literatury trzech epok: średniowiecza, renesansu i baroku i poprzedzona półtorastronicowym wprowadzeniem, w zasadzie streszczającym spis treści. Konstrukcję publikacji starannie

\footnotetext{
${ }^{1}$ „Ars moriendi” w literaturze polskiej XV i XVI w., Kraków 1987; Obraz i słowo. O powiazaniach w sztuce i literaturze XV-XVI wieku na przykładzie ,, ars moriendi”, Kraków 1991; Barokowa poezja epicedialna. Analizy, Kraków 1993; Trzy traktaty o sztuce umierania, Kraków 2015.

${ }^{2}$ Polska poezja świecka XV wieku, Wrocław 1997 (Biblioteka Narodowa, seria I, nr 60); Średniowieczna poezja łacińska w Polsce, Wrocław-Warszawa-Kraków 2007 (Biblioteka Narodowa, seria I, nr 310).

${ }^{3}$ Polsko-bazylejskie więzi kulturalne i literackie w XVI wieku, Kraków 1987 (UJ Rozprawy habilitacyjne, nr 124); Dwa wieki kulturalnych i literackich powiąań polsko-bazylejskich. 1433-1632, Kraków 2001.
} 
przemyślano - na każdą z części składa się pięć odpowiednio dobranych tematycznie studiów. Zbiór dopełnia Glosa wydawnicza - informacje o miejscu pierwotnej publikacji poszczególnych artykułów, aneks z tekstem Rozmowy Śmierci z Mistrzem Maciejem w edycji prof. Elwiry Buszewicz, skorowidz nazwisk i postaci oraz tytułów dzieł bezimiennych i spis ilustracji.

Nie dziwi, że aż trzy z pięciu studiów dotyczących literatury średniowiecza poruszają zagadnienia tanatologiczne. Wszak zapewne każdy współczesny literaturoznawca badający motyw śmierci w literaturze dawnej ma za sobą lekturę książek i artykułów Macieja Włodarskiego. W tekście Wyobrażenia śmierci w polskiej poezji średniowiecznej (s. 13-27) autor analizuje literackie obrazy śmierci, traktując ją z jednej strony jako zjawisko psychofizyczne, z drugiej jako motyw literacki śmierć uosobioną. Zastanawia się przy tym, co w wiekach średnich wpływało na ludzkie wyobrażenia o śmierci. Analiza obejmuje zarówno utwory w języku polskim, jak i łacińskim i wskazuje na to, że poezja w języku rodzimym dużo częściej porusza tematykę psychofizycznych doznań związanych z umieraniem. Dzieła po polsku przeznaczone były dla kręgu prostych odbiorców, na których lepiej oddziaływały „naturalistyczne” opisy niż konwencjonalne motywy, wpisujące się w tradycyjną topikę (elementem, który jeszcze mocniej wpływał na wyobraźnię prostego odbiorcy, były personifikacje śmierci). O wyobrażeniach śmierci w literaturze średniowiecznej zapewne można by napisać całe tomy, mimo to zaledwie czternastostronicowe studium Macieja Włodarskiego jest tekstem zadziwiająco „syntetycznym”. Autorowi udało się omówić temat, unikając wielosłowia, w sposób zwięzły, na najbardziej charakterystycznych przykładach literackich. Dzięki temu artykuł można uznać za jedną z podstawowych lektur czytelnika interesującego się tematyką wyobrażeń śmierci w literaturze wieków średnich.

Artykuł „Ars bene moriendi” Jakuba z Paradyża (s. 29-41) dotyczy popularnych traktatów dobrego umierania. Mediewista przedstawia znane traktaty artes bene moriendi, poczynając od jednego z najstarszych - De moralitate św. Cypriana z III w., pokrótce omawia trzy najpopularniejsze, ,wzorcowe” traktaty, by na ich tle szerzej zanalizować piętnastowieczny podręcznik dobrego umierania Jakuba z Paradyża. Badacz analizuje utwór na tle tradycji podręczników dobrego umierania, ale zwraca uwagę na cechy wyróżniające dzieło cystersa, stara się wyśledzić możliwe źródła traktatu, wskazuje nawiązania intertekstualne (biblijne, patrystyczne i klasyczne) i dokonuje analizy stylistycznej gatunku.

Z kolei studium zatytułowane „Dolus mundi”, czyli wiersz o zwodniczym świecie (s. 43-58) podejmuje problematykę popularnych średniowiecznych wierszy, których tematem była idea „pogardy świata” (contemptus mundi). Autor wziął na warsztat zaczerpnięty z manuskryptu lubiąskiego wiersz Sequitur dolus mundi (jest to satyra skierowana przeciwko przedstawicielom różnych stanów i zawodów), szczegółowo streścił i zanalizował utwór, a także wskazał różnice pomiędzy nim a przekazami z kodeksów zachodnich. Do studium został dołączony tekst Dolus mundi z kodeksu lubiąskiego. 
Kolejne syntetyczne studium - Lacińska poezja religijna $w$ Polsce średniowiecznej jako poprzedniczka poezji humanistycznej (s. 59-72) to przegląd najstarszych znanych utworów łacińskich powstałych na terenie Polski. Badacz omawia wybrane utwory należące do łacińskiej liryki religijnej: tropy i sekwencje, hymny czy cykle pozaliturgicznych liryków nazywane oficjami rymowanymi, zwracając uwagę na budowę poszczególnych utworów oraz środki artystycznego wyrazu. Celem artykułu było pokazanie bogactwa gatunkowego oraz tematycznego, a także dbałości twórców o różnorodność środków stylistycznych i motywów. Dziwi jedynie, jak niewiele miejsca poświęcił autor drugiej części tytułu, czyli nawiązaniom pomiędzy średniowieczną poezją religijną a poezją humanistyczną (zaledwie jeden ogólny przykład - Hymnów kościelnych Jana Dantyszka).

Ostatni tekst w części dotyczącej średniowiecza - Szesnastowieczna wersja średniowiecznej „Rozmowy Mistrza Polikarpa ze Śmiercia” (s. 73-85) stanowi analizę najpopularniejszego zabytku średniowiecznej poezji świeckiej w języku polskim - Rozmowy czy też Dialogu Mistrza Polikarpa ze Śmiercia. W zasadzie jest to porównanie szesnastowiecznej wersji Rozmowy, zatytułowanej Śmierci $z$ Mistrzem dwojakie gadanie, i znanego nam, o wiek starszego przekazu. Autor analizuje przekaz, który w 2018 r. został ogłoszony w sieci jako sensacja edytorska - utwór z 1542 r., rzekomo zawierający pełny tekst piętnastowiecznej Rozmowy. Maciej Włodarski, szczegółowo porównawszy fragmenty obu tekstów, dowodzi jednak, że jest to przeróbka, w której wprowadzono niefortunne zmiany, pominięto istotne motywy, a niektóre wersy są wręcz nielogiczne. Ponadto przekaz szesnastowieczny jest znacznie mniej staranny, jeśli chodzi o zachowanie rytmu wiersza - stał się on mniej potoczysty. Badacz krytycznie odnosi się także do tezy, iż autorem szesnastowiecznej przeróbki Rozmowy był sam Mikołaj Rej.

Artykuł o peregrynacjach polskiej młodzieży w XVI w. na zachodnie uniwersytety na przykładzie uczelni w szwajcarskiej Bazylei otwiera część publikacji dotyczącą literatury i kultury renesansu (Polacy w Uniwersytecie Bazylejskim w XVI stuleciu, s. 89-111). Polsko-szwajcarskie związki kulturalne to kolejny ważny temat w badaniach Włodarskiego. W tekście przede wszystkim przedstawiono poczet polskich studentów na Uniwersytecie Bazylejskim. Dane te zostały zaczerpnięte z metryki uniwersyteckiej, a gdy to było możliwe, autor przedstawił pokrótce dalsze losy studentów, ale skupił się przede wszystkim na odtworzeniu sieci kontaktów z profesorami uczelni i innymi wybitnymi postaciami szesnastowiecznej Bazylei. Jest to o tyle ważne, że poskutkowały one m.in. wydaniem na Zachodzie ważnych dzieł, np. De Republica emendanda Andrzeja Frycza Modrzewskiego. Ponadto kontakty te stanowią świadectwo wymiany myśli w środowisku intelektualnym Europy i - co autor zaznacza w podsumowaniu - liberalne poglądy bazylejskich profesorów z pewnością miały wpływ na ukształtowanie się polskiego protestantyzmu. Studium bez wątpienia stanowi ważny wkład w badania nad polsko-szwajcarskimi kontaktami kulturalnymi w czasach staropolskich. 
W kręgu zainteresowań badacza znalazły się nie tylko utwory o charakterze stricte literackim, ale także teksty wchodzące w skład tzw. ramy wydawniczej. Artykuł O listach dedykacyjnych Mikołaja Reja (s. 113-128) zaczyna się od krótkiego omówienia roli dedykacji od czasów najdawniejszych. Autor podkreśla ich szczególne znaczenie w humanizmie, analizuje i porównuje listy dedykacyjne, które wyszły spod pióra Reja, biorąc pod uwagę topikę tego gatunku, m.in. zasadę stosowności i przydatności książki dla adresata, a także topos „,afektowanej skromności”. Celem było zbadanie, jak wyglądają dedykacje Reja na tle tradycyjnych zasad epistolografii dedykacyjnej. Jak stwierdza autor, Nagłowiczanin umiał odcisnąć własne piętno na tym gatunku.

Dwa ostatnie teksty w części Renesans dotyczą prozy Jana Kochanowskiego. Wybór ten został umotywowany faktem, iż jego utwory prozatorskie - w przeciwieństwie do poezji - są mało znane i słabo zbadane. Celem studium $O$ stylu prozy Jana Kochanowskiego (s. 129-142) była przede wszystkim próba wskazania, jakie miejsce Jan z Czarnolasu zajmuje pośród renesansowych twórców mowy niewiązanej. Autor porównuje teksty prozatorskie Kochanowskiego z dziełami najwybitniejszych renesansowych prozaików, m.in. Stanisława Orzechowskiego, Jana Dymitra Solikowskiego i Łukasza Górnickiego, by w konkluzji stwierdzić, iż „pod względem sprawności konstrukcyjnej oraz jasności wysłowienia proza mistrza czarnoleskiego nie ustępuje dokonaniom literackim wybitnych nawet stylistów" (s. 141). Z kolei studium Proza polska lat 1550-1584 jako tto twórczości prozatorskiej Jana Kochanowskiego (s. 143-163) stanowi szczególnie interesujący przegląd mniej popularnych utworów prozatorskich drugiej połowy XVI stulecia. Badacz zwraca uwagę na różnorodność prozy tego okresu, dzięki czemu otrzymujemy klarowny obraz gatunkowo-tematyczny.

Kolejny artykuł został zatytułowany „Rozważanie o wyborze króla polskiego". Literacki dokument kalkulacji wyborczych z okresu pierwszych bezkrólewi (s. 165-184). Autor w Bibliotece Uniwersyteckiej w Bazylei odkrył anonimowy łaciński tekst Deliberatio in creando Rege Poloniae (Rozważanie o wyborze króla polskiego), w którym w sześciu krótkich wierszach opisano kandydatury do tronu polskiego. Najpewniej był to wyborczy tekst agitacyjny. Badacz, opierając się na tych sześciu strofach, przeprowadził pasjonujące śledztwo mające na celu zbadanie, o którym bezkrólewiu mowa w wierszach, i wskazanie domniemanego autorstwa. Dzięki szczegółowej analizie i wiedzy historycznej Maciejowi Włodarskiemu udało się ustalić datację tekstu między marcem a lipcem 1587 r. Ponadto do studium dołączony został niepublikowany wcześniej bazylejski tekst łaciński oraz przekład badacza.

Trzecią część książki, analizującą przykłady literatury barokowej, otwierają dwa teksty dotyczące łacińskiej i polskiej poezji Daniela Naborowskiego. Liryki łacińskie poety (O poezjach łacińskich Daniela Naborowskiego, s. 187199) są słabiej zbadane niż jego twórczość w języku rodzimym, tymczasem to w wierszach łacińskich twórca szlifował swój kunszt poetycki. Temat ten został 
rozwinięty w artykule Daniel Naborowski. Twórca poezji kunsztownej (s. 201-218). Maciej Włodarski interpretuje wiersze Naborowskiego na tle zjawisk społeczno-kulturalnych i religijnych przełomu wieków, biorąc pod uwagę niepewną kondycję człowieka tego okresu - czasów zwątpienia, kwestionowania prawd moralno-religijnych uznawanych dotychczas za stałe, niezmienne. Analiza wybranych liryków jest wyjątkowo szczegółowa i pieczołowita - ma na celu pokazanie bogactwa skojarzeń i pomysłowości poety, wykorzystywania rzadko stosowanych środków poetyckich (np. figura versus rapportati). Badacz demaskuje liczne, niekiedy trudne do uchwycenia nawiązania intertekstualne i mitologiczne poezji Naborowskiego, wskazuje najważniejsze motywy i toposy - jednym słowem pokazuje, na czym polega kunszt poety. W obu artykułach dowodzi, że „kontynuując tradycję humanistyczną, Naborowski zwracał się ku nowej poetyce, która dążyła do zaskoczenia, zadziwienia, olśnienia odbiorcy kosztem renesansowej harmonii” (s. 218).

Kolejne studium, o enigmatycznym, choć jak najbardziej pasującym do treści tytule Sen bogini (s. 219-229), stanowi porównanie dwu utworów, w których wykorzystano motyw uśpionych bohaterek: wiersza Dyskrecyja (1647) Jana Andrzeja Morsztyna oraz poematu weselnego Samuela ze Skrzypny Twardowskiego Piotrowi Opalińskiemu i Annie Sieniucance Epitalamijum (1661). Autor wskazuje podobieństwa i różnice między utworami i interpretuje je, odwołując się do motywów mitologicznych. Zestawiwszy liryczny utwór konceptystyczny i epitalamijną laudację, dowodzi, że ten sam motyw mitologiczny (sen bogini Wenus) w epoce kontrastów i przeciwieństw, jaką był barok, mógł zostać przedstawiony w zupełnie odmienny sposób w zależności od funkcji i poetyckiego warsztatu twórcy.

Artykuł Echo ,Godzinek o Niepokalanym Poczęciu Najświętszej Maryi Panny” w wierszu Stanisława Samuela Szemiota (s. 231-239) dotyczy powiązań pomiędzy wywodzącą się ze średniowiecza paraliturgiczną modlitwą, jaką były Godzinki o Niepokalanym Poczęciu Najświętszej Maryi Panny, a siedemnastowiecznym utworem ku czci Matki Bożej autorstwa Szemiota Barzo szczuply i krótki panegiryk na cześć i na chwałę Bogarodzicy Maryjej, czystej zawsze Panny. Tło dla interpretacji utworu stanowi ożywienie kultu Matki Bożej w epoce baroku, kiedy motywy mariologiczne pojawiały się w utworach zarówno poetów uznawanych dziś za wybitnych, jak i twórców minorum gentium. Badacz pokazuje, że Szemiot czerpał z Godzinek, o czym świadczą wspólne określenia i porównania maryjne. Co więcej, autor twierdzi, iż „utwór Szemiota stanowi próbę poetyckiej egzegezy kilku z wielu tytułów Maryi pojawiających się właśnie w Godzinkach" (s. 233). Szemiotowa interpretacja określeń Maryi bez wątpienia dowodzi związków pomiędzy formami religijności i mentalności ludzi średniowiecza i baroku, a także trwałości pewnych tradycji interpretacyjnych.

Ostatnie studium w zbiorze - Do dziejów teatru religijnego $w$ barokowym Krakowie (,,Śmierć dobra” 1690) (s. 241-250) - również dotyka specyfiki siedemnastowiecznej pobożności. Badacz wziął na warsztat druczek z 1690 r., będący programem dialogu, swego rodzaju scenariuszem widowiska zorganizowanego 
przy okazji inauguracji Kongregacji Dobrej Śmierci przy kościele Świętych Apostołów Piotra i Pawła w Krakowie. Jednym z przejawów działalności bractw religijnych, których wiele powstało w XVII stuleciu, były różnorodne uroczystości parateatralne. Sumariusz inscenizacji zestawia przykłady dobrej i złej śmierci, by obudzić w widzach pragnienie osiągnięcia „śmierci szczęśliwej”. Włodarski wydał w transkrypcji unikatowy, składający się z zaledwie dwóch kart druczek z Biblioteki Jagiellońskiej i dokonał jego analizy. Przede wszystkim zbadał źródła wszystkich przedstawionych w programie przykładów śmierci. Śmierć dobra ... nawiązuje do popularnych od początków XV w. traktatów dobrego umierania, o których badacz pisze w pierwszych tekstach tomu. Podejmując temat „sztuki dobrego umierania”, ostatni artykuł w tomie tworzy swoistą klamrę kompozycyjną.

Biorąc pod uwagę, iż mamy do czynienia $\mathrm{z}$ doświadczonym badaczem i wyselekcjonowanymi tekstami, nie jest zaskoczeniem, że lektura Staropolskim szlakiem stanowi wyjątkową przygodę intelektualną dla czytelnika zainteresowanego literaturą dawną. Warto jednak podsumować, z czego konkretnie to wynika. Przede wszystkim studia zamieszczone w tomie są bardzo różnorodne i świadczą o imponująco szerokim zakresie zainteresowań badawczych autora. Są to artykuły o literaturze trzech epok okresu staropolskiego. Maciej Włodarski pisze zarówno o utworach największych sław, jak i twórców minorum gentium, wydaje i interpretuje teksty anonimowe, nieznane wcześniej literaturoznawcom (jak odnalezione na półkach Biblioteki Uniwersyteckiej w Bazylei Rozważanie o wyborze króla polskiego), odkrywa przed czytelnikiem nieznane przekazy popularnych utworów (Śmierci z Mistrzem dwojakie gadanie) i chętnie podejmuje tematy zaniedbane (jak proza Kochanowskiego czy liryka łacińska Naborowskiego). Szczegółowe analizy poetyckie ukazują autora publikacji jako badacza o doskonałym przygotowaniu nie tylko polonistycznym, lecz także klasycznym. Wykorzystane w zbiorze cytaty opiera on na najnowszych edycjach krytycznych poezji dawnej. Zamieszczone w publikacji studia napisane są barwnym językiem, bez zbędnego wielosłowia i dłużyzn, dzięki czemu pracę czyta się z ogromną przyjemnością. W centrum zainteresowania Macieja Włodarskiego znajdują się przekazy literackie, jednak co konieczne - autor odwołuje się do wiedzy dotyczącej życia społecznego i politycznego, mentalności czy religijności człowieka dawnych wieków. Staropolskim szlakiem to nie jest synteza i publikacja z pewnością nie rości sobie praw do tego miana. To raczej świadectwo naukowej drogi doświadczonego badacza literatury dawnej. 